\title{
Optical DNA-DNA Homology in the Genus Listeria
}

\author{
T. HARTFORD* AND P. H. A. SNEATH \\ University of Leicester, P.O. Box 138, University Road, Leicester LE1 9HN, United Kingdom
}

\begin{abstract}
Twenty-three strains of the seven recognized Listeria species were studied by using DNA-DNA optical hybridization. The level of error in the data was low. Our results supported the results of Rocourt et al. (J. Rocourt, F. Grimont, P. A. D. Grimont, and H. P. R. Seeliger, Curr. Microbiol. 7:383-388, 1982), although there was some overlap between Listeria monocytogenes and Listeria innocua. We suggest that there may be more than one cluster in the species $L$. monocytogenes or the species may form a large spectrum of relatedness. The level of intraspecies homology in L. monocytogenes is very broad, as determined in both this study and other studies.
\end{abstract}

The members of the genus Listeria are gram-positive, nonsporing, motile rods. In the latest edition of Bergey's Manual of Systematic Bacteriology (13) Seeliger and Jones list five species (Listeria monocytogenes, Listeria innocua, Listeria welshimeri, Listeria seeligeri, and Listeria ivanovii) and three species incertae sedis (Listeria murrayi, Listeria levels of similarity of 81 to $87 \%$ (5). The strains of each species cluster at similarity levels of approximately $90 \%$.

In their DNA studies, Rocourt et al. (10) divided what was the $L$. monocytogenes complex into the five species that are recognized today; this division was supported by a small number of biochemical differences (11). However, only six

TABLE 1. Bacterial strains

\begin{tabular}{|c|c|c|c|}
\hline Species & Serotype & Strain $^{a}$ & Source \\
\hline \multirow[t]{7}{*}{ L. monocytogenes } & $1 / 2 a$ & C52 (= NCTC 7973) & Guinea pig mesenteric lymph node \\
\hline & 2 & $\mathrm{C} 200(=$ NCTC $5348=$ ATCC 19112$)$ & Cerebrospinal meningitis \\
\hline & $1 / 2 \mathbf{a}$ & $\mathrm{C} 201^{\mathrm{T}}\left(=\operatorname{NCTC} 10357^{\mathrm{T}}=\operatorname{ATCC} 15313^{\mathrm{T}}\right)^{b}$ & Rabbit \\
\hline & $3 \mathbf{a}$ & C202 $(=$ NCTC $5105=$ ATCC 19113) & Human \\
\hline & $4 b$ & C203 $(=$ NCTC $4885=$ ATCC 19115$)$ & Infant meningitis \\
\hline & $4 a$ & C228 $(=$ NCTC $5214=$ ATCC 19114 $)$ & Sheep brain \\
\hline & $4 \mathrm{c}$ & C231 (= NCTC 4883) & Fowl myocardial disease \\
\hline \multirow[t]{3}{*}{ L. innocua } & $\begin{array}{l}6 \mathrm{a} \\
6 \mathrm{~b}\end{array}$ & $\begin{array}{l}\text { C644 }\left(=\text { NCTC } 11288^{\mathrm{T}}=\operatorname{ATCC~} 33090^{\mathrm{T}}=\operatorname{SLCC~} 3379^{\mathrm{T}}\right) \\
\text { C645 }(=\operatorname{SLCC~} 3479)\end{array}$ & Cow brain \\
\hline & & JS21 & Raw chicken \\
\hline & & JS31 & Raw chicken \\
\hline L. welshimeri & $6 a$ & $\begin{array}{l}\mathrm{C} 1091^{\mathrm{T}}\left(=\mathrm{NCTC} 11857^{\mathrm{T}}=\operatorname{ATCC} 35897^{\mathrm{T}}\right) \\
\mathrm{C} 1172\end{array}$ & Decaying vegetation \\
\hline \multirow[t]{2}{*}{ L. seeligeri } & & $\mathrm{C} 1090^{\mathrm{T}}\left(=\mathrm{NCTC} 11856=\operatorname{SLCC} 3954^{\mathrm{T}}\right)$ & \\
\hline & 5 & $\begin{array}{l}\text { C1171 } \\
\text { C } 1087^{\mathrm{T}}\left(=\text { NCTC } 11846^{\mathrm{T}}=\text { ATCC } 19119^{\mathrm{T}}=\operatorname{SLCC} 2379^{\mathrm{T}}\right)\end{array}$ & $\begin{array}{l}\text { Placenta, ovine abortion } \\
\text { Sheep }\end{array}$ \\
\hline \multirow{4}{*}{ L. ivanovii } & 5 & C659 (= P L242) & Ovine abortion \\
\hline & 5 & C663 ( = P L72) & \\
\hline & 5 & C666 (= P L234) & Ovine abortion \\
\hline & 5 & $\mathrm{C} 667(=\mathrm{P}$ L102B) & \\
\hline L. grayi & & $\begin{array}{l}\text { C214 (= SLCC 332/64) } \\
\text { SLCC } 7211\end{array}$ & Chinchilla feces \\
\hline L. murrayi & & $\mathrm{C} 1174^{\mathrm{T}}\left(=\mathrm{NCTC} 10812^{\mathrm{T}}=\operatorname{ATCC} 25401^{\mathrm{T}}\right)$ & Cornstalks \\
\hline
\end{tabular}

${ }^{a}$ C, University of Leicester Culture Collection; NCTC, National Collection of Type Cultures; ATCC, American Type Culture Collection; SLCC, Special Listeria Culture Collection; JS, isolated at University of Leicester; P, Pritchard.

${ }^{b} \mathrm{~T}=$ type strain.

grayi, and Listeria denitrificans, which was recently reclassified as Jonesia denitrificans [12]). The first five taxa may be termed the L. monocytogenes complex.

Rocourt et al. (10) confirmed the low levels of DNA-DNA homology among $L$. grayi, $L$. murrayi, and other strains which were first observed by Stuart and Welshimer $(15,16)$. However, when numerical taxonomy is used, $L$. murrayi and L. grayi group closely with $L$. monocytogenes strains at

\footnotetext{
${ }^{*}$ Corresponding author.
}

reference strains were used by these authors, and the intraspecies range of pairing values within $L$. monocytogenes sensu stricto was considerable (more than $35 \%$ ).

DNA-DNA pairing values suggest that there is a much greater variation between species than the phenotypic characteristics imply, perhaps because a large portion of the genome is not expressed phenotypically.

The large variation in pairing values within $L$. monocytogenes sensu stricto raises the question of whether there may be two (or more) clusters within the species; alternatively, the strains may form a spectrum in terms of relatedness rather than distinct groups, and this second possibility is 
TABLE 2. Standard deviations obtained from replications of Listeria pairing data

\begin{tabular}{|c|c|c|c|}
\hline Strains & $\begin{array}{l}\text { Avg \% } \\
\text { pairing }\end{array}$ & $n^{a}$ & SD $(\%)$ \\
\hline $\mathrm{C} 52$ and $\mathrm{C} 200$ & 67.0 & 2 & 2.5 \\
\hline C52 and C231 & 69.3 & 3 & 3.3 \\
\hline C52 and C201 & 89.4 & 4 & 1.0 \\
\hline $\mathrm{C} 52$ and $\mathrm{C} 228$ & 56.8 & 2 & 1.6 \\
\hline C52 and C644 & 71.9 & 7 & 3.2 \\
\hline C52 and JS31 & 46.6 & 3 & 0.7 \\
\hline C52 and C1090 & 52.2 & 3 & 1.8 \\
\hline C52 and C1091 & 52.6 & 5 & 3.0 \\
\hline $\mathrm{C} 52$ and $\mathrm{C} 1172$ & 44.1 & 2 & 1.0 \\
\hline C52 and C1087 & 44.7 & 3 & 0.9 \\
\hline C52 and C663 & 30.4 & 3 & 0.6 \\
\hline C52 and C667 & 36.8 & 3 & 1.8 \\
\hline C52 and C659 & 33.0 & 3 & 3.2 \\
\hline C52 and C666 & 35.7 & 2 & 4.3 \\
\hline C52 and SLCC 7211 & 23.4 & 4 & 1.7 \\
\hline $\mathrm{C} 200$ and $\mathrm{C} 202$ & 81.5 & 3 & 2.5 \\
\hline $\mathrm{C} 200$ and $\mathrm{C} 231$ & 73.8 & 2 & 2.1 \\
\hline $\mathrm{C} 200$ and $\mathrm{C} 1090$ & 55.0 & 3 & 0.6 \\
\hline $\mathrm{C} 200$ and $\mathrm{C} 663$ & 41.8 & 2 & 2.6 \\
\hline $\mathrm{C} 202$ and $\mathrm{C} 203$ & 85.1 & 2 & 1.5 \\
\hline C203 and C644 & 62.3 & 2 & 2.1 \\
\hline $\mathrm{C} 203$ and $\mathrm{C} 663$ & 34.5 & 2 & 0.5 \\
\hline $\mathrm{C} 203$ and $\mathrm{C} 214$ & 18.9 & 2 & 6.2 \\
\hline $\mathrm{C} 231$ and $\mathrm{C} 644$ & 44.6 & 2 & 3.4 \\
\hline $\mathrm{C} 231$ and $\mathrm{C} 1171$ & 53.4 & 4 & 2.3 \\
\hline $\mathrm{C} 231$ and $\mathrm{C} 667$ & 27.1 & 2 & 0.5 \\
\hline C231 and C666 & 38.4 & 3 & 1.2 \\
\hline C228 and JS21 & 51.2 & 3 & 0.6 \\
\hline $\mathrm{C} 228$ and $\mathrm{C} 1091$ & 51.7 & 3 & 1.6 \\
\hline C644 and C645 & 94.9 & 2 & 4.2 \\
\hline C644 and C1090 & 50.3 & 2 & 0.6 \\
\hline C644 and C1091 & 49.7 & 9 & 2.5 \\
\hline C644 and C1172 & 45.5 & 3 & 0.8 \\
\hline C644 and C663 & 27.8 & 3 & 1.6 \\
\hline C644 and C1174 & 15.9 & 2 & 4.0 \\
\hline $\mathrm{C} 1171$ and $\mathrm{C} 645$ & 44.9 & 4 & 3.4 \\
\hline JS21 and JS31 & 95.0 & 3 & 1.5 \\
\hline JS31 and C1090 & 59.7 & 2 & 3.5 \\
\hline JS31 and C1091 & 56.2 & 2 & 0.7 \\
\hline JS31 and C1087 & 38.9 & 2 & 0.1 \\
\hline JS31 and C214 & 24.9 & 2 & 2.6 \\
\hline $\mathrm{C} 1090$ and $\mathrm{C} 1171$ & 93.5 & 2 & 0.4 \\
\hline $\mathrm{C} 1090$ and $\mathrm{C} 1091$ & 46.2 & 3 & 1.7 \\
\hline $\mathrm{C} 1090$ and $\mathrm{C} 1172$ & 53.5 & 2 & 0.7 \\
\hline $\mathrm{C} 1090$ and $\mathrm{C} 1087$ & 37.3 & 5 & 4.4 \\
\hline $\mathrm{C} 1090$ and $\mathrm{C} 663$ & 43.0 & 3 & 3.1 \\
\hline $\mathrm{C} 1090$ and $\mathrm{C} 659$ & 35.4 & 2 & 1.8 \\
\hline $\mathrm{C} 1090$ and $\mathrm{C} 214$ & 13.6 & 2 & 0.2 \\
\hline C1171 and C663 & 35.9 & 2 & 0.4 \\
\hline C667 and C214 & 11.7 & 2 & 2.1 \\
\hline $\mathrm{C} 1091$ and $\mathrm{C} 1172$ & 91.6 & 2 & 0.5 \\
\hline C1091 and C1087 & 34.9 & 2 & 0.4 \\
\hline $\mathrm{C} 1091$ and $\mathrm{C} 659$ & 24.9 & 3 & 4.3 \\
\hline C1091 and SLCC 7211 & 10.5 & 2 & 0.6 \\
\hline $\mathrm{C} 1172$ and $\mathrm{C} 1087$ & 42.4 & 2 & 1.1 \\
\hline $\mathrm{C} 1087$ and $\mathrm{C} 659$ & 86.2 & 2 & 1.9 \\
\hline C1087 and C1174 & 14.3 & 2 & 0.8 \\
\hline C667 and C659 & 83.4 & 3 & 2.6 \\
\hline C667 and C666 & 84.9 & 2 & 0.1 \\
\hline C667 and SLCC 7211 & 16.8 & 2 & 11.3 \\
\hline $\mathrm{C} 214$ and $\mathrm{C} 1174$ & 84.3 & 2 & 3.2 \\
\hline
\end{tabular}

${ }^{a} n$, number of replications. supported by the small number of biochemical differences between strains.

\section{MATERIALS AND METHODS}

Bacterial strains and cultivation. The Listeria strains used in this study are listed in Table 1 . The collection numbers and sources of original isolation are given where they are known. Species identifications were taken from publications by experts on the genus $(5,10)$. Listeria strains were grown in tryptone soya broth (Oxoid) at $35^{\circ} \mathrm{C}$ and were harvested in the late exponential phase.

DNA extraction. A variation of the method of Marmur (8) was used to extract and purify DNAs.

Bacteria were lysed by incubating them with a lysozyme solution (final concentration, $1 \mathrm{mg} \mathrm{ml}^{-1}$ ) for $1 \mathrm{~h}$ at $37^{\circ} \mathrm{C}$, followed by 1 to $2 \mathrm{~h}$ of incubation with proteinase $\mathrm{K}$ (final concentration, $0.1 \mathrm{mg} \mathrm{ml}^{-1}$ ) and $2 \%$ (wt/vol) sodium dodecyl sulfate. The protein was removed by subjecting preparations to phenol-chloroform extractions, and the DNA was spooled onto a glass rod. RNA was removed by treatment with RNase, followed by proteinase $K$ treatment and phenolchloroform extractions. The DNA was selectively precipitated with isopropanol, washed with $70 \%$ ethanol, and dissolved in $0.1 \times \mathrm{SSC}$ buffer $(1 \times \mathrm{SSC}$ is $0.15 \mathrm{M} \mathrm{NaCl}$ plus $0.015 \mathrm{M}$ sodium citrate).

DNA diluted to a concentration of 200 to $300 \mu \mathrm{g} \mathrm{ml}^{-1}$ in $2 \times$ SSC was sheared by using a French press to a length of 344 to $514 \mathrm{bp}$. The sheared DNA was dialyzed overnight at $4^{\circ} \mathrm{C}$ in 500 volumes of $2 \times$ SSC buffer.

DNA-DNA homologies. Purified sheared DNA samples were diluted prior to use with $2 \times$ SSC to give an $A_{260} 1.55 \pm$ 0.05 (i.e., a concentration of 75 to $80 \mu \mathrm{g} \mathrm{ml}^{-1}$ ).

A set of matched semimicro quartz cuvettes equipped with Teflon stoppers were used for the study described below. A volume of $700 \mu \mathrm{l}$ was used for the homology experiments. A Philips model PU8700 spectrophotometer equipped with a cell programmer and a Peltier heating block was programmed to melt the DNA and follow its renaturation at the optimal renaturation temperature $\left(T_{\text {or }}\right)$.

The melting temperature $\left(T_{m}\right)$ was determined with the spectrophotometer by increasing the temperature by $1^{\circ} \mathrm{C}$ $\min ^{-1}$ until the DNA was completely single stranded (90 to $96^{\circ} \mathrm{C}$ depending on the strain). The $T_{\text {or }}$ was assumed to be $T_{m}$ $-25^{\circ} \mathrm{C}$ in the same buffer system (4).

Renaturation. Samples were denatured in the spectrophotometer; when the absorbance no longer continued to increase, the temperature was held steady for $5 \mathrm{~min}$ to ensure that all of the DNA was single stranded. The temperature was decreased rapidly by setting the programmer to $0^{\circ} \mathrm{C}$. When the temperature was $T_{\text {or }}+10^{\circ} \mathrm{C}$, the programmer was set to the desired renaturation temperature. The whole cooling process took 2.5 to $3 \mathrm{~min}$. The change in absorbance at the $T_{\text {or }}$ was followed for 20 to $30 \mathrm{~min}$. The rate of renaturation was determined from the straight-line portion of the graph by using the equation of DeLey et al. (4).

Data were represented by using the unweighted pairedgroup method of analysis (UPGMA) (14) and principalcoordinate analysis (14).

Errors were estimated by using the methods described by Hartford and Sneath (6).

\section{RESULTS}

The average percentage of pairing determined for each pair of strains (from $n$ spectrophotometer runs, where the 


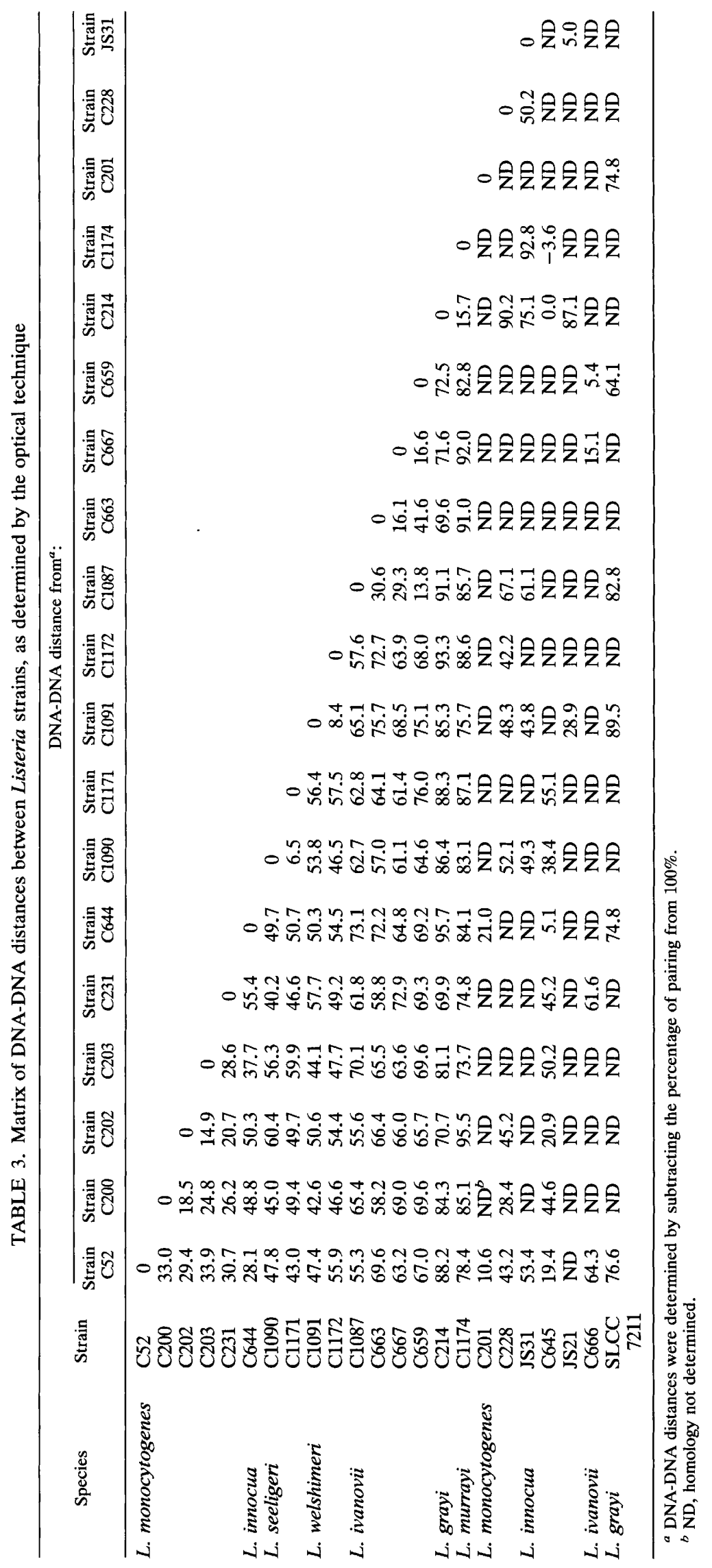




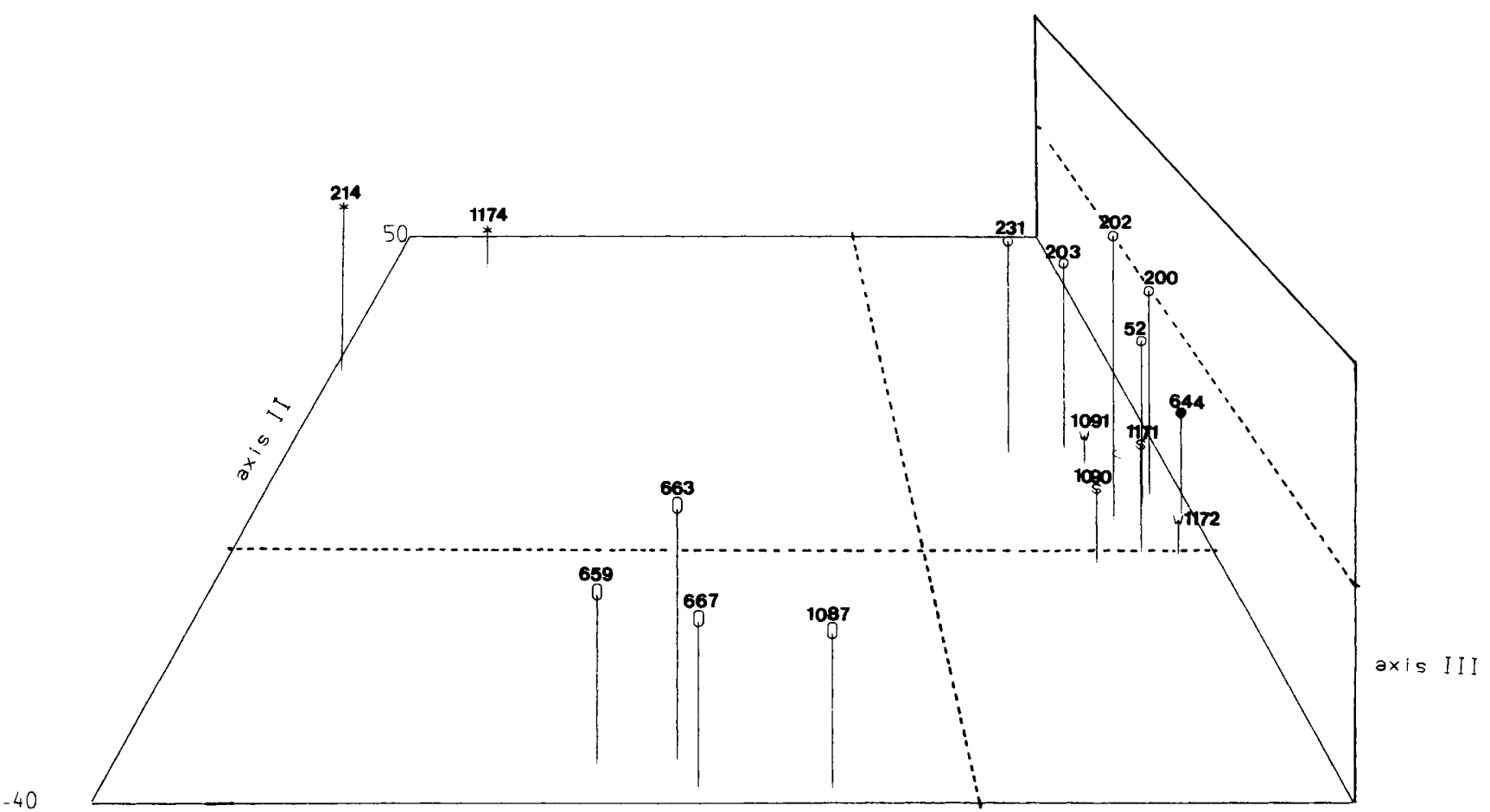

FIG. 1. UPGMA dendrogram and three-dimensional ordination from principal-coordinate analysis of the complete matrix ( 16 by 16 ) (Table 3) of DNA distances. Symbols: $O, L$. monocytogenes;,$L$.

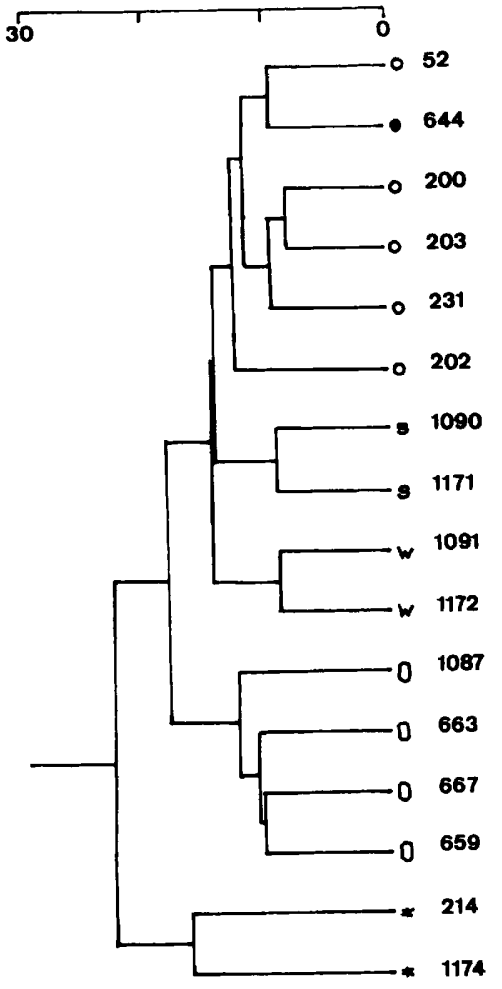

number of replications was greater than 1) and the standard deviation are shown in Table 2 . A complete matrix (16 by 16) was derived from the data. By subtracting from 100 , the matrix of relatedness was converted to a matrix of distances (Table 3), which were used in a principal-coordinate program innocua; $\mathrm{O}$, L. ivanovii; $\mathrm{s}$, L. seeligeri; $\mathrm{w}$, L. welshimeri; *, L. grayi and $L$. murrayi.

(TRUPCA) on the Leicester University Vax Cluster. The UPGMA and principal-coordinate ordination results from the matrix (16 by 16) of strains are shown in Fig. 1.

The UPGMA showed that all of the strains cluster at a distance of 23. L. grayi and L. murrayi are easily separated by eye. $L$. ivanovii strains are grouped together; however, the remaining strains appear to be very closely related. Strains C52 and C644 associate before attachment to the rest of the L. monocytogenes strains. A single-linkage cluster analysis gave very similar results; the differences from the UPGMA analysis are (i) strains C52 and C644 do not join first and (ii) $L$. monocytogenes strains and $L$. innocua strains are separated, but the branch lengths between the strains of these species are extremely short.

Levels of error in replication experiments were measured as the standard deviations for the DNA-DNA pairing values for each pair of strains (6). Pairing values were divided into 10 bands at $10 \%$ intervals, and the errors were averaged over each $10 \%$ range. The average error was plotted against the midpoint of the band (Fig. 2). The level of error seemed to be independent of the percentage of pairing, although the levels of error were higher at very low pairing values and high pairing values (more than 90\%). There were no zero errors or violating triangles when we used the TRUDNA program (Leicester University Vax Cluster) (6).

\section{DISCUSSION}

The range of variation of in levels of DNA relatedness within the species $L$. monocytogenes was very large, as in the study of Rocourt et al. (10), suggesting that there is more than one cluster or a spectrum of relatedness. 


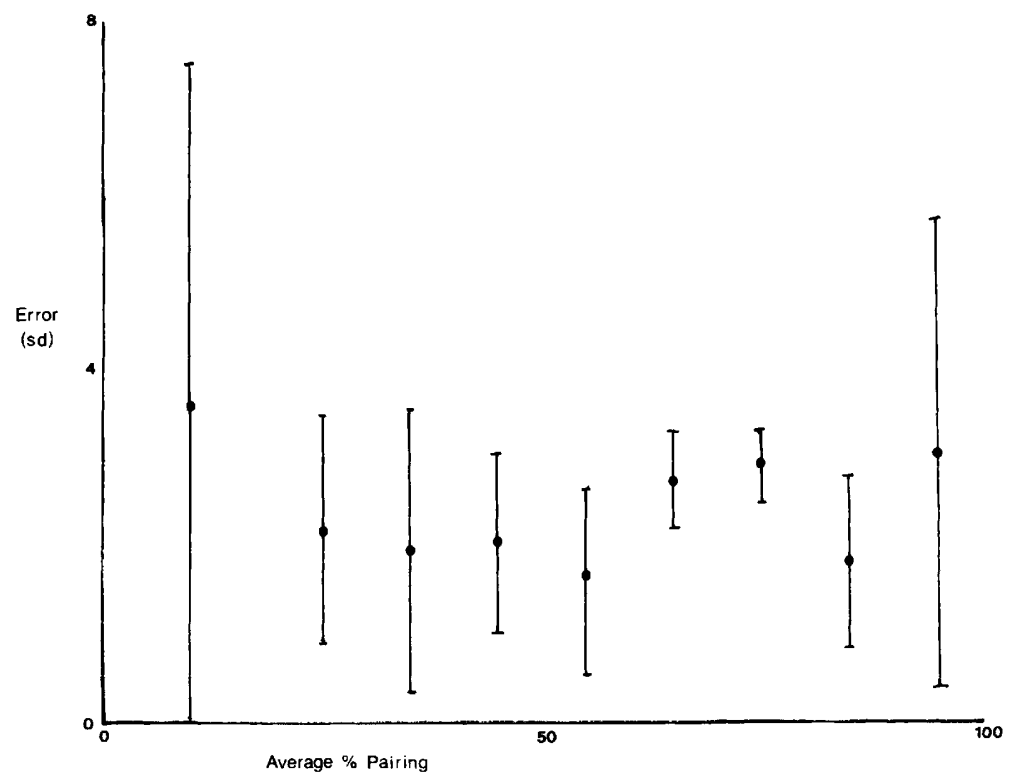

FIG. 2. Relationship between error from replications and average percent pairing experiments performed with Listeria strains when the optical technique was used. The error was the average standard deviation. Pairing values were divided into 10 bands at $10 \%$ intervals, and the results were plotted as the midpoints of the bands, as means (dots), and as 1 standard deviation above and below the mean (vertical lines).

L. grayi and L. murrayi appear to be distinct from the other species, although it is not clear from our data whether $L$. grayi can be separated from $L$. murrayi. Some strains of L. monocytogenes are more closely related to $L$. innocua strains than to other $L$. monocytogenes strains. Rocourt et al. (10) separated these two species on the basis of DNA homology data, but the L. monocytogenes strain that was their only reference strain from this species did not seem to be typical of the species. Strain C52 does not seem to be a particularly typical representative of the species $L$. monocytogenes. Collins et al. (3) compared the 16S rRNA nucleotide sequences of the type strains of Listeria species, and a UPGMA dendrogram of their data suggests that L. monocytogenes and $L$. innocua come together before they join the other species, although all species are very closely related.

The wide range of values which we obtained supports the hypothesis that there is either a spectrum of relatedness or two or more clusters in the species $L$. monocytogenes sensu stricto, as suggested by work in which multilocus enzyme electrophoresis was used $(1,2,9)$.

A few Listeria strains were used in both this study and the study of Rocourt et al. (10), and the pairing values for these strains are shown in Table 4. As shown in other comparisons of DNA-DNA pairing methods, the endonuclease technique is much more stringent than both the filter technique and the optical technique. In this study although the ordination gave results that were broadly similar to the results of Rocourt et al. (10), the values were always higher than the values for similar or identical pairs in the study of Rocourt et al.

Several values below $30 \%$ were obtained when this technique was used. Huss et al. (7) found that values below $30 \%$ were rarely obtained at the DNA concentration which we used and were meaningless. If this is true, then $L$. grayi and L. murrayi may be less closely related to the other five species than is suggested above.

As determined by numerical taxonomy and other chemical relatedness studies, Listeria species, especially $L$. monocytogenes, $L$. innocua, L. welshimeri, and L. seeligeri are very closely related, although $L$. ivanovii is somewhat distinct; DNA pairing data strongly support this conclusion, and there seem to be no strongly defined clusters among the four species.

TABLE 4. Pairing values, as determined by the optical technique and the S1 nuclease technique ${ }^{a}$

\begin{tabular}{|c|c|c|c|c|c|c|c|c|}
\hline \multirow{3}{*}{ Strain } & \multicolumn{8}{|c|}{$\%$ Pairing } \\
\hline & \multicolumn{2}{|c|}{ Strain C52 } & \multicolumn{2}{|c|}{ Strain C644 } & \multicolumn{2}{|c|}{ Strain C1091 } & \multicolumn{2}{|c|}{ Strain C1090 } \\
\hline & $\begin{array}{c}\text { S1 } \\
\text { nuclease } \\
\text { technique }\end{array}$ & $\begin{array}{c}\text { Optical } \\
\text { technique }\end{array}$ & $\begin{array}{c}\text { S1 } \\
\text { nuclease } \\
\text { technique }\end{array}$ & $\begin{array}{c}\text { Optical } \\
\text { technique }\end{array}$ & $\begin{array}{c}\text { S1 } \\
\text { nuclease } \\
\text { technique }\end{array}$ & $\begin{array}{c}\text { Optical } \\
\text { technique }\end{array}$ & $\begin{array}{c}\text { S1 } \\
\text { nuclease } \\
\text { technique }\end{array}$ & $\begin{array}{c}\text { Optical } \\
\text { technique }\end{array}$ \\
\hline C52 & 100 & 100 & & & & & & \\
\hline C644 & 53 & 71.9 & 100 & 100 & & & & \\
\hline C1091 & 42 & 52.6 & $46 / 44^{b}$ & 49.7 & 100 & 100 & & \\
\hline C1090 & 24 & 52.2 & 24 & 50.3 & 28 & 46.2 & 100 & 100 \\
\hline
\end{tabular}

${ }^{a}$ Data from reference 10 and Table 2.

${ }^{b}$ Pairing values in which DNA from each strain was radiolabelled in turn. 


\section{ACKNOWLEDGMENT}

This research was supported by a grant from SERC and Philips Scientific Co.

\section{REFERENCES}

1. Bibb, W. F., B. G. Gellin, R. Weaver, B. Schwartz, B. D. Plikaytis, M. W. Reeves, R. W. Pinner, and C. Y. Broome. 1990. Analysis of clinical and food-borne isolates of Listeria monocytogenes in the United States by multilocus enzyme electrophoresis and application of the method to epidemiologic investigations. Appl. Environ. Microbiol. 56:2133-2141.

2. Boerlin, P., J. Rocourt, and J.-C. Piffaretti. 1991. Taxonomy of the genus Listeria by using multilocus enzyme electrophoresis. Int. J. Syst. Bacteriol. 41:59-64.

3. Collins, M. D., S. Wallbanks, D. J. Lane, J. Shah, R. Nietupski, J. Smida, M. Dorsch, and E. Stackebrandt. 1991. Phylogenetic analysis of the genus Listeria based on reverse transcriptase sequencing of 16S rRNA. Int. J. Syst. Bacteriol. 41:240-246.

4. DeLey, J., H. Cattoir, and A. Reynarts. 1970. The quantitative measurement of DNA hybridization from renaturation values. Eur. J. Biochem. 12:133-142.

5. Ferusu, S. B., and D. Jones. 1988. Taxonomic studies on Brochothrix, Erypsipelothrix, Listeria and atypical lactobacilli. J. Gen. Microbiol. 134:1165-1183.

6. Hartford, T., and P. H. A. Sneath. 1990. A review: experimental error in DNA-DNA pairing: a survey of the literature. J. Appl. Bacteriol. 68:527-542.

7. Huss, V. A. R., H. R. Festl, and K. H. Schleifer. 1983. Studies on the spectrophotometric determination of DNA hybridization from renaturation rates. Syst. Appl. Microbiol. 4:184-192.

8. Marmur, J. 1961. A procedure for the isolation of deoxyribo- nucleic acid from microorganisms. J. Mol. Biol. 3:208-218.

9. Piffaretti, J.-C., H. Kressebuch, M. Aeschbacher, J. Bille, E. Bannerman, J. M. Musser, R. K. Selander, and J. Rocourt. 1989. Genetic characterization of the bacterium Listeria monocytogenes causing epidemic disease. Proc. Natl. Acad. Sci. USA 86:3818-3822.

10. Rocourt, J., F. Grimont, P. A. D. Grimont, and H. P. R. Seeliger. 1982. DNA relatedness among serovars of Listeria monocytogenes sensu lato. Curr. Microbiol. 7:383-388.

11. Rocourt, J., A. Schrettenbrunner, and H. P. R. Seeliger. 1983. Differentiation biochemique des groupes genomiques de Listeria monocytogenes (sensu lato). Ann. Inst. Pasteur Microbiol. 134A:65-71.

12. Rocourt, J., U. Wehmeyer, and E. Stackebrandt. 1987. Transfer of Listeria denitrificans to a new genus, Jonesia gen. nov., as Jonesia denitrificans comb. nov. Int. J. Syst. Bacteriol. 37:266270.

13. Seeliger, H. P. R., and D. Jones. 1986. Genus Listeria Pirie, 1940 , 383 ${ }^{\mathrm{AL}}$, p. 1235-1245. In P. H. A. Sneath, N. S. Mair, M. E. Sharpe, and J. G. Holt (ed.), Bergey's manual of systematic bacteriology, vol. 2. The Williams \& Wilkins Co., Baltimore.

14. Sneath, P. H. A., and R. R. Sokal. 1973. Numerical taxonomy: the principles and practice of numerical classification. W. H. Freeman, San Francisco.

15. Stuart, S. E., and H. J. Welshimer. 1973. Intragenic relatedness of Listeria Pirie. Int. J. Syst. Bacteriol. 23:8-14.

16. Stuart, S. E., and H. J. Welshimer. 1974. Taxonomic reexamination of Listeria Pirie and transfer of Listeria grayi and Listeria murrayi to a new genus, Murraya. Int. J. Syst. Bacteriol. 24:177-185. 